\title{
Bold New Frontiers of Astrobiology
}

\section{Wickramasinghe NC}

Buckingham Centre for Astrobiology (BCAB), Buckingham University, UK

${ }^{*}$ Corresponding author: Wickramasinghe NC, Buckingham Centre for Astrobiology (BCAB), Buckingham University, UK, Tel: +44-777-838-9243; E-mail: ncwick@gmail.com

\section{Recieved date: March 14, 2016; Accepted date: March 15, 2016; Published date: March 18, 2016}

Copyright: (c) 2016 Wickramasinghe NC. This is an open-access article distributed under the terms of the Creative Commons Attribution License, which permits unrestricted use, distribution, and reproduction in any medium, provided the original author and source are credited.

\section{Editorial}

New research is directing Astrobiologists to venture into a once forbidden territory - life and evolution from space. The rewards of taking this brave step will be great; turning away from the facts would be fraught with danger.

Over three decades ago the theory that comet dust could bring viable bacteria and viruses to the Earth and that this process drives biological evolution was first proposed [1,2]. In 1982 in a monograph entitled "Proofs that life is cosmic" we wrote thus:

"If Fred Hoyle and the present writer had knowledge that evolution was an entirely terrestrial affair then of course it would be hard to see how viruses from outside the Earth could interact in an intimate way with terrestrially evolved cells, but we have no such knowledge, and in the absence of knowledge all one can say is that viruses and evolution must go together. If viruses are incident from space then evolution must also be driven from space. How can this happen? Viruses do not always attack the cells they enter. Instead of taking over the genetic apparatus of the cell in order to replicate themselves, a viral particle may add itself placidly to one or other of the chromosomes. If this could happen for the sex cells of a species, mating between similarly infected individuals leads to a new genotype in their offspring, since genes derived from the virus are copied together with the other genes ......"

Since this time the body of evidence that supports such ideas has grown steadily. Genome sequencing studies carried out since 2000 have yielded ample evidence of viral "footprints" in the genomes of many and diverse phyla - ranging from humans to insects. Some $8 \%$ of the human genome is found to be derived from sequences similar to infective retroviruses, probably representing ancestral infections similar to HIV that became fixed in the DNA of the evolving germ line $[3,4]$. By comparing the human genome with genomes of other primates a timeline of sequential retroviral inserts has also been obtained. Yohn et al. [5] have stated that their data are consistent with a retroviral infection that bombarded the genomes of chimpanzees and gorillas independently and concurrently, 3-4 million years ago, with no horizontal transmission being implied. Recently Diehl et al. [6] have shown that a specific endogenous retrovirus group (ERV-Fc) has somehow come to be spread globally across many mammalian species about 33-15 million years ago. There have also been indications that the later evolutionary development of hominids, including enhanced cognitive capacity, may also have viral origins [7].

An externally driven viral involvement appears to have been identified in the development of mammalian placenta in ancestors of all mammals including humans about 150 million years ago [8]. The possibility that similar viruses endowed with evolutionary potential continue to arrive with comet dust in the present day cannot be ignored. Experiments to test this hypothesis in whichever way possible must be considered high priority in future astrobiology research [9].

A team of scientists led by Thiel have recently conducted an experiment in which plasmid DNA was placed on the surface of a TEXUS-49 sounding rocket that was blasted out into space and subsequently re-entered the atmosphere [10]. In this experiment the conditions endured by the DNA would closely mimic what actually happens in the high speed entry of viruses attached to meteor/comet dust. The result that a fraction of DNA remained viable is a clear indication that extraterrestrial viruses can indeed arrive at the Earth in viable form.

In view of these new facts it is timely and prudent that astrobiology research should take seriously the search for viruses that may even now be arriving from space and thus contributing to the predominant biomass of the planet which is actually in the form of viruses. Some of the new viral input might on occasion pose a potential pandemic threat and it is possible that their early detection could lead to the deployment of efficient mitigation strategies. The recently initiated Japanese program to look for bacteria / viruses at the height of the International Space Station will be a step in the right direction. The Tanpopo project (https://en.wikipedia.org/wiki/Tanpopo_(mission)) started last year will hopefully confirm the survival of bacteria in the near-Earth environment at the distance of the ISS orbit and thus verify earlier results of Cockell et al. [11]. More importantly, it would be able sample and monitor the environment outside the ISS for ambient or in-falling microbes that may be of extraterrestrial origin. In so doing it would significantly extend earlier attempts to isolate microbes in the stratosphere at heights of $41 \mathrm{~km}[12,13]$.

\section{References}

1. Hoyle F, Wickramasinghe NC (1980) Evolution from Space. Dent JM and Sons, London, UK.

2. Hoyle F, Wickramasinghe NC (1982) Proofs that Life is Cosmic. Memoirs of the Institute of Fundamental Studies, Sri Lanka.

3. Griffiths DJ (2001) Endogenous retroviruses in the human genome sequence. Genome Biology 2: 1017.1-1017.5.

4. Villesen P, Aagaard L, Wiuf C, Pedersen FS (2004) Identification of endogenous retroviral reading frames in the human genome. Retrovirology 1: 32 .

5. Yohn CT, Jiang Z, McGrath SD, Hayden KE, Khaitovich P, et al. (2005) Lineage-Specific Expansions of Retroviral Insertions within the Genomes of African Great Apes but Not Humans and Orangutans. PLoS Biol 3: e110.

6. Diehl WE, Patel N, Halm K, Johnson WE (2016) Tracking interspecies transmission and long-term evolution of an ancient retrovirus using the genomes of modern mammals. ELife 5: e12704.

7. Villareal LP (2004) Can viruses make us human? Proc Am Phil Soc 148: 296-323. 
8. Katzourakis A (2013) Paleovirology: inferring viral evolution from host genome sequence data. Phil Trans Roy Soc Lond 368: 1626.

9. Wickramasinghe NC, Steele E (2016) Dangers of adhering to an obsolete paradigm: Could Zika virus lead to a reversal of human evolution. Astrobiol Outreach 4: 147.

10. Thiel CS, Tauber S, Schutte A, Schmitz B, Nuesse H, et al. (2014) Functional Activity of Plasmid DNA after Entry into the Atmosphere of Earth Investigated by a New Biomarker Stability Assay for Ballistic Spaceflight Experiments. PLoS ONE 9: e112979.
11. Cockell CS, Rettberg P, Rabbow E, Olsson-Francis K (2011) Exposure of phototrophs to 548 days in low Earth orbit: microbial selection pressures in outer space and on early Earth. ISME J 5: 1671-1682.

12. Harris MJ, Wickramasinghe NC, Lloyd D, Narliker JV, Rajaratnam P, et al. (2002) The detection of living cells in stratospheric samples. Proceedings of the SPIE Conference 4495: 192.

13. Wainwright M, Wickramasinghe NC, Narliker JV, Rajaratnam P (2003) Microorganisms cultured from stratospheric air samples obtained at $41 \mathrm{~km}$, FEMS Microbiol Lett 218: 161-165. 